\title{
The Characteristics of the Hollywood Musical Cinema during the Golden Age in The Lion King
}

\author{
Di Liu \\ Foreign Languages Studies \\ Anshan Normal University \\ Anshan, China
}

\begin{abstract}
Taking the film The Lion King (1994) as an example, this paper analyzes the characteristics of the Hollywood musical cinema during the Golden age embodied in the film, through the aspects of the narrative structure, the character image and the soundtrack, and so forth. Through the analysis of the characteristics of the Hollywood musical cinema in the film, this paper aims to address a more profound understanding of the Hollywood musical cinema, and therefore, it hopes to enhance the strengths and accelerate the development process for the Chinese film industry.
\end{abstract}

Keywords-Hollywood Musical; Golden age; Narrative structure; Heroism complex

\section{INTRODUCTION}

From the beginning of the 1930 s to the 1950 s, it is considered as the golden age of the film music in the Hollywood cinema. Additionally, this is the most prosperous period of the classic Hollywood movies, and it is also the period of studio system from prosperity to decline.

The vigorous development of the Hollywood musical cinema has been attracted by many experts and scholars to study it, but most of the researches are mainly around the four major characteristics of the Broadway musical, which are entertainment, comedy, popular and commercial, and there are few studies on other aspects of the Hollywood musical cinema. For this very reason, based on the previous research, this paper will summarize the characteristics of the Hollywood musical cinema during the golden age, from three aspects of the narrative structure, characters' construction and film music to heighten the reader's understanding of the Hollywood musical cinema.

Through studying the dramatic narrative structure, heroism complex and leitmotif mode in The Lion King, this paper will explore the characteristics of the Hollywood musical cinema, and it will strengthen the readers' understanding of the characteristics of the Hollywood musical cinema during the golden age.

\section{THE CHARACTERISTICS OF THE HOLLYWOOD MUSICAL CINEMA DURING THE GOLDEN AGE}

Under the influence of European musical, the Hollywood musical cinema is an art form which is rooted in the development of native culture. Until present, the Hollywood musical cinema is still widely spread as a representative of the American culture. The Hollywood musical cinema has its unique aesthetic core, the capable of absorbing the different arts, culture and the achievements of advanced technology, and it has become a symbol of contemporary culture, and has been welcomed worldwide.

\section{A. The Characteristics of the Narrative Structure}

Film is a comprehensive art, which combines music, painting, architecture, dance, drama and other art forms. Film narrative pays attention to plot transforms and careful manmade action, and so many dramatic techniques such as suddenly change and conflicts and so forth, these includes dramatic plot, dramatic action, dramatic conflict, and dramatic situation, and so forth (Brown, 1994).

Most American animated films, especially the Disney animation cinema, the narrative structure is the frame, the template or the formula of the film maker's narrative. The classical Hollywood narrative structure is the most common and the most dominant narrative structure. The cause and effect relationship is accelerated by a motivated, goal oriented character creating change by overcoming the obstacles standing between them and the attainment of their goal (Flinn, 1992).

The narrative of the classic Hollywood film is focused on the actions of the characters. Usually they use the protagonist to drive the narrative. The development of classical narratives demonstrates a person's character and the will to struggle with the obstacles through the psychological motivation. This narrative element is usually described by a major narrative (usually a romantic) entangled with a secondary narrative, such as a business or a crime (Flinn, 1992). This narrative structure has a clear beginning, middle and end, and usually there is a clear resolution. Using actors, events, cause and effect relationships, the main points and sub points are the essential features of this type of narrative.

\section{B. The Characteristics of the Character Images}

The Hollywood in the American is known as the World Dream Works, which has created countless heroes and myths, and it has created the images of many types of heroes. In general, the hero in the American movies either relates to the national destiny and national interests, or defends the equality, freedom and justice, or embodies the wishes of the Americans 
longing for a better democracy, dignity and peace. The hero shines everywhere with humanity. However, striping off their luxurious appearance, it is also obvious to realize that heroism is always the leading role of the American film. The American idealism and heroism has been fully reflected in these heroes. There has a strong response to the elements of heroism; these heroes are always self-reliance and self-improvement, and pursuit of freedom and equality with their motivations. They seek justice, and they help those who need help. For the Americans, only through self struggle, can they achieve success, and the achievement of their efforts is the reflecting of the meaning and the value of their life (Kalinak, 1992). And only rely on self struggle to achieve success, will it won everyone's sincere admiration and respect.

\section{The Characteristics of the Film Music}

Since the end of 1929, after the Great Depression, Hollywood has been entered a period of rapid development. The system of the film industry has been improved, especially the establishment of the studio system, and concomitant with the high precision division mode of operation, which was the producer-centered, and the big stars dotted with. At the same time, the formations of five major Hollywood studios, such as MGM, Paramount, Warner Bros., RKO and 20th Century Fox, have promoted the Hollywood movies continuously producing commodities (Flinn, 1992). During the period, the Hollywood movies have mostly produced by these studios, and therefore, this formed the Hollywood golden age.

Leitmotif (Leitmotiv) refers to a motivation throughout the whole piece of music. The leitmotif is a short form of musical language, and the length of it is usually one or two summaries. A leitmotif or a theme is a short, constantly repeating musical phrase which usually associated with a particular person, place, or idea (Gorbman, 1987). In large musical works, they usually utilize leitmotif to symbolize a particular character, realm, things or concepts motives or themes. Whenever this character (or state, etc) appear, sometimes its recurrent leitmotif's rhythm or pitch will be a slight change (Gorbman, 1987).

One of the basic writing skills that refers to the use of musical leitmotif to symbolize the character, the story and the use of repetition. It is a distinctive "label", through the organic synthesis of instrumental music and vocal music, it is a sound signal used by composers to reveal the development of the plot, and this is the band to perform in the show through different instruments (Kalinak, 1992). But sometimes composers would lock the leitmotif in a certain kind of tone, even when they use a certain timbre to represent a certain character, a certain mood or event, for example, they often using the clarinet and bassoon's low tone to represent sinister or repression, and represent the camp scene or welcome ceremony with trumpet sound, and use the cello treble to represent actor's heartfelt words, and so forth. These leitmotif tones are utilized commonly and freely.

Leitmotif can also be used to represent abstract ideas, it is able to speak for an object which is not sung, and therefore it causes an anthropomorphic effect. Leitmotif enhances the musical's notation, so that the audience can identify the character or a variety of moods which mean special from lengthy and continuous musical, and it also enhances the symbol of musical, to make the audience recognize characters with special emotions in a long and continuous musical.

\section{THE CHARACTERISTICS OF THE HOLLYWOOD MUSICAL CINEMA IN THE LION KING}

\section{A. Film Synopsis}

The Lion King is an American animated feature directed by Roger Allers and Rob Minkoff, and it was produced by Walt Disney Feature Animation in 1994. Until present, The Lion King still maintains the highest grossing traditionally animated film in history, and it belongs to the period of the Renaissance of Disney. The Lion King's music and story has received universal acclaim from critics. Since it was released in 1994, this musical film has won more than 783 million US dollars at the box office in the world, as a result, it has become the year's most successful films.

The Lion King tells about Simba's journey of self discovery. Simba is the inheritor of the Pride Lands, he grows up as a confident young lion, until his father Mufasa was killed by his evil uncle Scar, Simba is forced to grow up. With the feeling of being guilty for the death of his father, Simba runs away from the Pride Lands, and then he encounters a funny group of two people, warthog Pumba and meerkat Timon. They teach Simba a precious lesson of life. Simba eventually finds his true love and returns to rescue the Pride Lands, he eventfully regains what he deserves and punishes Scar.

\section{B. The Dramatic Narrative Structure}

In order to seize the audience's attention, the dramatic narrative structure can create a tense atmosphere, and the sense of crisis is not only fulfilled with the main characters in the film, but also in the audience's psychological imagination.

The Pride Lands in the film is on the heights of the prairie, it takes everything in a glance. When the sun shines the vast land through the clouds, it is reflecting a king's magnanimity. The huge stone skillfully spelled out a letter "K", which clearly conveys the message that "this is the place where the king lives, and this is the center of the Kingdom's power". In the contrast with the Pride Lands, the elephant graveyard looks very eerie, the hole is piled with an elephant bones, when we speak we can hear the echo, the dark environment is full of elephant bones. It's really creepy.

Everything by the light touches is the Pride Lands, but the darkness place where the light cannot touches is the place of hyenas. Mufasa does not allow little lion Simba to go to the place where the light can not touches like the elephant graveyard, but Simba feels curious about these places, where he has never been to before. For this very reason, breaking down his father's orders, he and Nana enter into the elephant graveyard secretly. If Mufasa has not arrived in time, they will become the dinner of the three hyenas. This scene deepens the conflict between light and darkness.

When the king Mufasa was in control of the Pride Lands, the whole kingdom is full of vitality, all people carry out their own duties, and the land is filled with the gold, yellow and 
other warm colors. However, when the evil Scar is ruling the Pride Lands, the vegetation is withered, and the rivers are dried up, there is no food and water, everything has been destroyed, the land is filled with bones like the elephant graveyard. It creates an atmosphere of depressing and stifling.

\section{The Heroism Complex}

Throughout American classic cinema, regardless of the choice of what kind of theme, all contains the spiritual core of American heroism, and the heroism complex is actually demonstrated by personal presence as the basic premise of the core of American culture and values (Kalinak, 1992).

In the film, Scar persuades Simba that he should be responsible for the death of his father, thus Simba fled the Pride Lands and would not come back. Scar on the one hand persuades Simba to leave with ulterior motivation; on the other hand, he tries his best to kill Simba. With fear and guilt, after Simba running away from his hometown the Pride Lands, he gets to know a strange but enthusiastic warthog Pumbaa and his fellow mongoose Timon. Getting along with them, Simba gradually accepts their philosophy of life, which is "Hakuna Matata" (means no worries), Simba feels very relaxed and happy everyday. With the passage of time, Simba grows up to a handsome lion, but the past life has been lingering in his mind.

By chance, Simba meets up with his childhood sweetheart Nana. She tells him that since Scar became the king, he has ordered the hyenas taking over the Pride Lands. Everything in the land therefore has been destroyed, she persuades Simba to come back to the Pride Lands. For Simba, one part of his life is the freedom, the other part is the responsibility to his kingdom, and it is really a difficult choice for him. If he still would to live freely, he must abandon the safety of his kingdom, but if he wants to save the lions of the Pride Lands, he must give up the current life of ease.

Then shaman Rafiki also finds Simba, Rafiki teaches a much different doctrine to the grown Simba, he let Simba discover the meaning of his heritage as the true Lion King and inheritor of Mufasa's throne. Perhaps Rafiki is the only one who truly understands how every creature, in his or her own way, fits into the Circle of Life. With his guidance, Simba has been aware of his father's spirit lies in him so that he must accept the responsibility of his destined role. In order to save his kingdom, he gives up his yearning for life and comes back to the Pride Lands without any hesitation. He finally recaptures his position, and he defeats Scar. The battle is finally over, Simba's friends come forward to admit him as a new and legitimate king.

In addition, Simba has the courage to correct errors. Simba flees from the Pride Lands due to his remorse, he stays a carefree life with Timon and Pumbaa. But after he realizes the dangerous situation of the Pride Lands, he dare to face up to his mistakes and is brave to take the responsibility. Mistakes are inevitable, it is the right to choose whether one can avoid of it or learn from it. But it should not be simply shirked the responsibility after one makes mistakes, the best solution is to find a way to correct the error.
As a young lion, Simba is filled with curious, adventure, and almost stupid brave, always full of curiosity for the new things. He was so energetic that he could even make the most horrible place into an adventure, and he is so brave, rather than running away, he is able to fight with his enemies, when his friend was in trouble.

\section{The Leitmotif Mode}

Without those memorable musical moments where the characters burst into song to advance the story, the Disney animated film will be incomplete. The soundtrack of The Lion King are produced by Elton John and Hans Zimmer, who are the top music producer of the world and the famous orchestrator, it has won the 67th Oscar Best Music, Original Song and Best Music, Original Score. They play their respective advantages, and they combine the symphony with the rock and roll wonderfully, so the music of this film either in style or in form, are unique. Its lively music can fully and delightfully demonstrate the authentic of nature, it makes the audience feel like living in truly Africa.

When the heavy choral music starts (scene $75^{\prime} 15^{\prime \prime}-8^{\prime} 10^{\prime \prime}$ ), the cinema scene turns to the panorama of nature, and then the sky covers with dark clouds and heavy rain, thunder and lightning, at this time the theme music "This Land" appears, which indicates the frustrations and hardships of which Simba need to obstacle. With the plot gradually pushes forward, and the theme music in the film changing constantly, the music stops in the moment (scene 35'58'- 36'21"), when Mufasa fell off the edge of a cliff, only the Simba's cry can be listened, echoed in the empty and silence valley. When Simba finds the body of his father (scene $36^{\prime} 21^{\prime \prime}-38^{\prime} 49^{\prime \prime}$ ), the softly theme music "This Land" plays by the strings and harmonic band evolving into a slow funeral march, the chorus sung softly with string orchestra, the music becomes mildly bleak, therefore, audiences would deeply realize Simba's helplessness, self-blame and the feelings of grief.

Suddenly the music changes (scene $38^{\prime} 51^{\prime \prime}-39^{\prime} 33^{\prime \prime}$ ), in the showcase of symphony orchestra, three hyenas are chasing Simba, and the speed of the music becomes a fast tempo, the soundtrack renders the tension and discomfort of the scene. After a period of twists and turns, Simba grows in another land happily. When Nana and the elders persuade him to go back and save the kingdom, Simba is really hesitating. Then the elders come to the lake with Simba (scene 65'51"-66'34"), the reflection of Simba is shown on the surface of the lake, a slow and soft music rises up, the theme music "This Land" sounds again, Simba becomes full of passion and confidence, it indicates the beginning of a new life of Simba, then the orchestral theme suddenly rises (scene 66'34"-67'44"), vigorous and lively music functions as father reminds. The suddenly change of the music indicates the psychological changes of Simba.

At the end of the film (scene $80^{\prime} 56^{\prime \prime}-82^{\prime} 21^{\prime \prime}$ ), when everything comes back to peace, Simba becomes the king of the Pride Lands, the theme music "This Land" rises again, with the strings playing, the theme music plays a role of resonance in the emotion of revealing and rendering atmosphere. 


\section{CONCLUSION}

Through the above analysis and demonstration, on the basis of previous researches on the four characteristics of the Broadway musical such as entertainment, comedy, popular, commercial, taking the film The Lion King as an example, this paper has analyzed the narrative structure, the character image and the film music of the Hollywood musical cinema during the golden age. It has concluded the three major characteristics of the Hollywood musical cinema during the golden age, which are the dramatic narrative structure, heroism complex and Leitmotif mode. Therefore, this paper has enhanced the understanding of the characteristics about the Hollywood musical cinema during the golden age from the analysis of the perspectives of its dramatic narrative structure, the lively character images and its touching and original film music in the film.

\section{REFERENCES}

[1] Brown, Royal S., Overtones and Undertones: Reading Film Music, Berkeley: University of California Press, 1994.

[2] Flinn, Carol, Strains of Utopia: Gender, Nostalgia, and Hollywood Film Music, Princeton University Press, 1992.

[3] Gorbman, Claudia, Unheard Melodies: Narrative Film Music, Blooming: Indiana University Press; London: British Film Institute, 1987.

[4] Kalinak, Kathryn, (ed.) Setting the Score: Music and the Classical Hollywood Film, Madison: University of Wisconsin Press, 1992. 